\title{
Impact Mobile Service Quality, Switching Cost Financial, Procedural and Relational to Satisfaction and Loyalty
}

\author{
Faiq Ulfi $^{1}$, Maya Ariyanti ${ }^{2}$ \\ faiqulfi07@gmail.com ${ }^{1}$, letterbox.maya@gmail.com² \\ Postgraduate Student Telkom University ${ }^{1}$, Lecturer Telkom University ${ }^{2}$
}

\begin{abstract}
Competition in the telecommunications industry in retaining and acquiring customers is very important in supporting the company's revenue. This is closely related to the churn value of the company. This study aims to investigate whether factors such as mobile service, switching costs financial, procedural \& relational affect on customer satisfaction and loyalty as an indicator of service in improving company churn. This study uses data churn, number of customers, number of network services for the 2018 period from the telco company. The technique in sampling uses nonprobability -purposive sampling. The number of samples are 120 respondents. This study proves that mobile service, switching costs financially and relational positive effect. but procedural have negative effect on customer satisfaction and loyalty of telco company.
\end{abstract}

Keywords:Mobile Service Quality; Switching Cost; Satisfaction; Loyalty; Churn Rate.

\section{Introduction}

The growth of internet usage in Indonesia has a good development [3]. This is a good condition in adding telco customers as internet service providers where network services have reached all of Indonesia. Based on data from the mobile economy global 2018[35], the Indonesia is ranked $4^{\text {th }}$ which penetration in 2017 is $73 \%$ and is expected in 2025 to be $77 \%$ and based on Asosiasi Penyedia Layanan Internet Indonesia (APLII 2017) the growth of internet users in Indonesia has also positive experience[3]. Service improvements to customers are also done so that customers are comfortable using the service. The service is the opening of shop in the city center, Mobile service (car service) in each district and telco partners. Network development is also carried out by company where there are 1,4K $2 \mathrm{G}$ networks, 2,6K 3G networks and 1,7K LTE networks in 2018. It is expected add convenience to customer in using services and get positive value. 
Based on the report mentioned above that there is a good increase on customers but these conditions must be compared with customers who stop or move to other operators problems, since the period from May to December 2018 there has been a steady decline in the number of customers[36]. The problem very influential on company profits and a systematic solution is needed to find out the cause of the decline in the number of customers. research shows that the decline in subscribers is due to several factors. these factors are studied and influence how much and find a solution to the problem.

\section{Literature Review}

Mobile quality is a study of telecommunications quality using several factors compiled using a systematic hierarchy. This is used so that the company knows the factors used in the improvement program. Mobile serqual consist of billing, competency, convenience, customer serving, net qual, tariff and VAS [1][2][9]. Switching cost is the value used in the form of time, capital, and effort to move services. Switching cost consist of switching cost financial that related with fiancial loss, switching cost relational that related loss of business relationships or good partners and switching cost procedural that related losing the old procedures that are familiar and comfortable are replaced by new difficult procedures[6][29]. Customer satisfaction is good perception of the conditions or results obtained by the customer which is related on customer expectations. Previous studies have interpreted that to improve customer satisfaction by increasing product quality, service, and price by considering savings and in accordance with market needs so that it will increase growth, profit and sustainability of the company[17][18][19][24]. Loyalty is a situation where customers are loyal in using products and services continuously. Based on research before to increase customer loyalty on customert the company must have Interaction and ask questions to customers so that feedback is obtained on the company, create a customer loyalty program for example Creating Institutional Tie, and Win-Backs program that programs used to attract customers who have moved[14,24]. the number of customers leaving or leaving a supplier or service within a certain period. This can occur because of dissatisfaction by customers, lower prices from similar services, better marketing from competitors. that customers who leave the services and services of the company are very closely related to customer loyalty. Research on customers who move now is very important because to get new customers requires a greater cost than retaining customers[10][15][22]. 


\section{Research Methode}

This study takes data from the city of Pekanbaru using the google questionnaire method or google form. The data collection period in this study was carried out for two months and obtained as many as 120 respondents, while the data taken consisted of two categories, namely the first is personal data and the second is data related to questions on research variables. In this research also is using quantitative method because the data is related with value or number given by sample (primary data) and churn data (secondary). On measurenet of scale in this research is using ordinal scale with 5 levels that is strongly agree (5), agree (4), normal (3), disagree (2), and strongly disagree (1). The population on this research is all user that subscribe telco operator on pekanbaru city. From slovin formula or power B apps the sample get minimum is 100 but on this research using 120 repondent. The research using SPSS and SEM-PLS to test and process the data. The SPSS used to checked of condition that the data is not normal distribution. After check the result from SPSS is suitable, so directly using SEM-PLS to process the data. In secondary process consist of two testing, first is outer model or indicator test and second is inner model or hypothesis test. Outer model test consist of convergent validity, discriminant validity, and reability. Inner Model consist of $\mathrm{R}^{2}$ result and T-statistic value. In this study using reflective testing because it is based on causality relationships where reflective indicators are caused by constructs, covariance values between indicators are high where all indicators will change simultaneously or indicators affect each other if one indicator changes, all indicators indicate the same thing which eliminates one the indicator will not change the meaning of the construct, and all variables can be connected to other variables.

\section{Data Analysis}

\subsection{Distribution Test (SPSS)}

This test is used to determine whether the sample data obtained is normally distributed or abnormal. This serves to determine the pattern of the distribution of the samples obtained. The results obtained that the sample gives a value of 1 a number of 89 , gives an assessment of number 2 as many as 166, giving a value of number 3 as much as 625 , giving a value of 4 as much as 1582 and giving a number of numbers as much as 1738 . The mean value of the data obtained is 4,122 and the value of the standard deviation of 0.9469 . From the results above it can be concluded that the value does not follow the normal distribution. 


\subsection{Descriptive Analysis}

From the calculation in the variable index table, Table 1, shows that the Mobile Service quality variable is in the good category with a value of 83.57. Respondents felt that Telco network services, value-added services, tariffs, competencies to customers, bills, customer services and convenience had met the needs of respondents. The highest sub-index value on this mobile service is found in the ease of payment methods where the value is 87.83 , while the value required special attention to the ease of changing the package is 79.00. The second variable is procedural switching cost in either category where the value is 74.43. In this case difficulties in the initial arrangement and problems with newly used services will arise if changing services is the consideration of respondents where a portion of the condition is a significant contributor. The third variable is switching financial costs in the good category of 75.33. In this case the problem of losing points, bonuses, discounts and extra services as a long-time customer, if you have to switch to another operator and the initial cost, new installation costs, or activation fees if switching to another operator becomes an important matter that is considered by respondents. The fourth variable, namely relational switching costs in both categories 84.75 . In this case the respondent noticed that the problem of comfort in using telco services and the constraints of calling to respondents if replacing telco services was important.

Table 1. Index Value of Variabel

\begin{tabular}{cc}
\hline Variabel & Index Value \\
\hline Mobile serqual & $83.57 \%$ \\
SW Procedural & $74.43 \%$ \\
SW Financial & $75.33 \%$ \\
SW Relational & $84.75 \%$ \\
Satisfaction & $85.2 \%$ \\
Loyalty & $85.67 \%$ \\
\hline
\end{tabular}

\subsection{Structural Equation Modelling-Partial Least Square (SEM-PLS)}

In this study, the hypothesis was tested using the SEM-PLS method. From this research model, it is divided into two, namely endogenous or dependent variables (satisfaction and loyalty) and exogenous variables or independent variables (mobile service, switching cost financial, relational and procedural).

The stages in SEM-PLS analysis are measure of the outer model and the inner model (structural model). After measuring the outer model has been completed, the inner model analysis continues. Analysis of inner models is used 
to ensure that each measurement variable has reliability and validity before structural analysis between variables.

\subsubsection{Evaluation of Measurement Model (Outer Model)}

In this study, to evaluate the outer model which is reflective construct using construct validity, convergence validity, discriminant validity, composite validity and mean variance extracted (AVE). Table 2 . show that validity is based on assigning factor values and cross loads. Factor values and cross load values of more than 0.5 are considered significant. Based on Table 3 . The correlation matrix between variables and the square root of AVE can be seen that the value of AVE is lower than the square root value of AVE, so it can be concluded that the research model has a good descriminant.

Table 2. Construct Reliability and Validity

\begin{tabular}{lccc}
\hline Variabel & $\begin{array}{l}\text { Cronbach's } \\
\text { Alpha }\end{array}$ & CR & $\begin{array}{l}\text { Average Variance } \\
\text { Extracted (AVE) }\end{array}$ \\
\hline Loyalty & 0.876 & 0.924 & 0.801 \\
Mobile SerQual & 0.965 & 0.968 & 0.592 \\
Satisfaction & 0.881 & 0.927 & 0.809 \\
Switching Cost Financial & 0.724 & 0.876 & 0.780 \\
Switching Cost Procedural & 0.795 & 0.866 & 0.621 \\
Switching Cost Relational & 0.731 & 0.880 & 0.787 \\
\hline
\end{tabular}

Table 3. Correlation matrix variables and square root of AVE

\begin{tabular}{lcc}
\hline Variabel & (AVE) & Square Root AVE \\
\hline Loyalty & 0.801 & 0.895 \\
Mobile SerQual & 0.592 & 0.769 \\
Satisfaction & 0.809 & 0.899 \\
Switching Cost Financial & 0.780 & 0.883 \\
Switching Cost Procedural & 0.621 & 0.788 \\
Switching Cost Relational & 0.787 & 0.887 \\
\hline
\end{tabular}

\subsubsection{Evaluation of Structural Model (Inner Model)}

The evaluation of the Inner model aims to test the hypothesis about the influence of exogenous variables on exogenous. Evaluation of structural models can use the $\mathrm{R}$ value or use the value of the GOF (good of fit) evaluation. Regarding the calculation of the value of $\mathrm{R}$ is used in evaluating structural models with values for endogenous variables with good criteria if equal to 0.67 , moderate is 0.33 and weak is 0.19 . Based on Table 4. the value of the $\mathrm{R}$ square model is known that for loyalty and satisfaction the value is above 0.67 which means the value is good. Based on table 5. goodnes of fit is known by calculating the square root 
of $\mathrm{R}$ multiplications with AVE. Where $\mathrm{R}^{2}$ is an endogenous construct while AVE is the mean variance. The recommended GOF index value is greater than 0.36 [12]. The calculation results show that the GOF value of loyalty and satisfaction is large.

Table 4. R Square

\begin{tabular}{lccc}
\hline Variabel & R Square & $\begin{array}{c}\text { R Square } \\
\text { Adjusted }\end{array}$ & Status \\
\hline Loyalty & 0.772 & 0.762 & Good \\
Satisfaction & 0.784 & 0.777 & Good \\
\hline
\end{tabular}

Table 5. Goodnes Of Fit

\begin{tabular}{lcccc}
\hline Variabel & AVE & R Square & R square Adjusted *AVE & Status \\
\hline Loyalty & 0.801 & 0.772 & 0.618 & Big \\
Satisfaction & 0.809 & 0.784 & 0.634 & Big \\
\hline
\end{tabular}

\subsubsection{Hypotesis}

After making sure the results of the inner and outer models are in accordance with the criteria, then hypothesis testing is then performed on the model. Hypothesis testing is done using the evaluation of T-statistical values (structural models). In this test, if the T statistic value is greater than 1.96 ( $\alpha$ with a value of $5 \%$ ), it is considered to have a significant effect. Table 6 , shows the results of testing the hypotheses of the structural model. For example hypothesis from Mobile Serqual to Loyalty is positif and significant, This indicates that any changes in the mobile serqual variable will affect customer satisfaction and loyalty. This can be seen from the sub-variables of mobile serqual, one of which is related to service quality and network area. These factors have a positive effect on customers. 


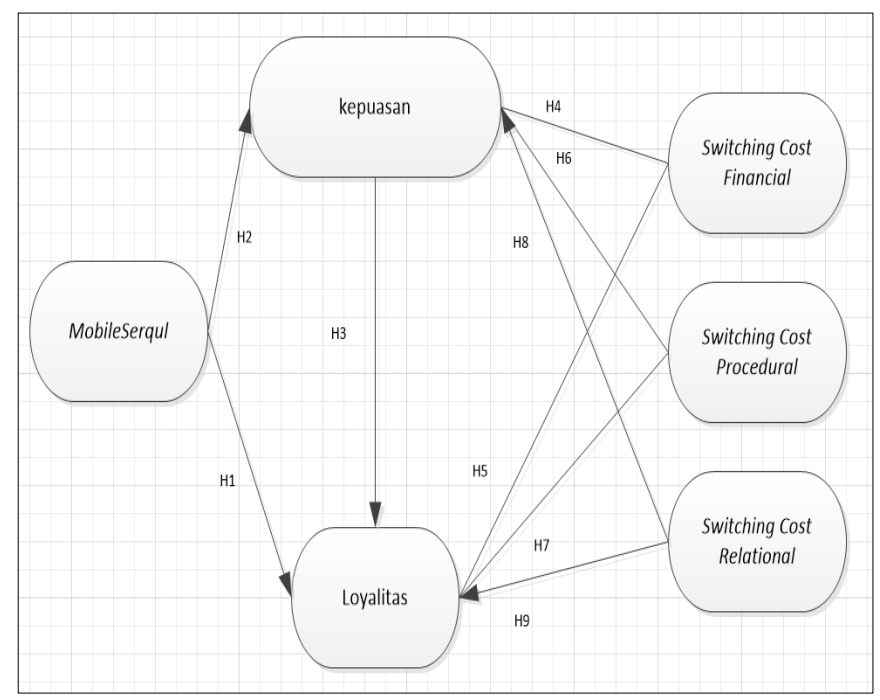

Pic 1. Diagram Relation

Table 6. Hypothesis

\begin{tabular}{lccccc}
\hline Relation & $\begin{array}{c}\text { Original } \\
\text { Sample }\end{array}$ & $\begin{array}{c}\text { Sample } \\
\text { Mean (M) }\end{array}$ & $\begin{array}{c}\text { Standard } \\
\text { Deviation }\end{array}$ & T-Statistic & Summary \\
\hline Mobile SerQual -> Loyalty & 0.394 & 0.381 & 0.120 & 3.274 & Pos-Sig \\
Mobile SerQual -> Satisfaction & 0.522 & 0.529 & 0.104 & 5.018 & Pos-Sig \\
Satisfaction -> Loyalty & 0.297 & 0.313 & 0.107 & 2.775 & Pos-Sig \\
Switching Cost Financial -> Loyalty & 0.080 & 0.075 & 0.089 & 0.904 & Pos-noSig \\
Switching Cost Financial -> Satisfaction & 0.016 & 0.013 & 0.061 & 0.265 & Pos-noSig \\
Switching Cost Procedural -> Loyalty & -0.021 & -0.014 & 0.090 & 0.235 & Neg-noSig \\
Switching Cost Procedural -> Satisfaction & -0.062 & -0.064 & 0.084 & 0.736 & Neg-noSig \\
Switching Cost Relational -> Loyalty & 0.197 & 0.190 & 0.117 & 1.691 & Pos-noSig \\
Switching Cost Relational -> Satisfaction & 0.443 & 0.435 & 0.110 & 4.042 & Pos-Sig \\
\hline
\end{tabular}

\section{Conclusion}

Influence of Mobile Service quality, Financial and Relational Cost Switching has a positive effect on satisfaction and loyalty. However, only switching procedural costs negatively affect telco customer satisfaction and loyalty. Mobile Service quality, Switching Cost Financial and Relational have a good value which is evidenced by the index variable values above $68-84$ while satisfaction and loyalty are very good value that is above 85 . Hypothesis testing results indicate that mobile service, switching costs financial, and relational have a positive and significant effect on satisfaction and loyalty, while procedural switching costs that have a negative effect on customer satisfaction 
and loyalty of telco. From the T-Statistics test the most influential value is the mobile service to customer satisfaction by 5,018 , while the lowest value is the value of procedural switching costs to loyalty.

\section{Suggestion}

Based on the results of this study, increasing the value of satisfaction and loyalty can be done on improving the mobile service variable about the ease in changing the package being used by customers and the switching cost variable is to facilitate the initial arrangement of services for new customers by the company. Based on the above research results, the company should look at the procedural switching cost variable where the value is negative and the variable is low correlation. Increasing these variables means keeping customers from moving to other services. The influence of research variables on loyalty is $77.2 \%(\mathrm{R}$ square), so there is still a potential for improvement of $22.8 \%$ where it is outside the variables that have not been included in the study. The potential for improvement can be used on social, cultural and psychological variables [26].

\section{References}

[1] Abu-Lai, A. A.-E. (2016). Mobile SERVQUAL: A comparative analysis of customers' and managers' perceptions. Emerald, International Journal of Quality \& Reliability Management.

[2] Alper Ozer, M. T. (2013). The Effect Mobile Service Quality DImension s on customer Satisfaction. Socail and Behavioural Journal-Elsevier, 428.

[3] APJII. (2017). Penetrasi \& Perilaku Pengguna Internet Indonesia. Jakarta: APJII.

[4] Astini, R. (2008). Mediasi dan Pengaruh Switching Cost terhadap Loyalitas Pelanggan GSM. ResearchGate.

[5] Blythe, J. (2005). Essential Of Marketing. England: Pearson Education Limited.

[6] Burnham, T. A., Frels, J. K., \& Mahajan, V. (2003). Consumer Switching Cost: A Topology, Antecendent, Consequenses. Academy of Marketing Science. Journal; , 109.

[7] Donald R. Cooper, P. S. (2006). Business Research Methods. US: McGraw-Hill.

[8] Douligeris, C. (1994). Telecomunications Quality Study Using The Analytic Hierarchy Process. IEEE Journal On Selected Areas in Communication, 2.

[9] Eugenia Y. Huang, S.-W. L.-C. (2015). M-S-QUAL: Mobile service quality measurement. Elseivier - Electronic Commerce Research and Applications, 7.

[10] Eui-Bang Lee, J. K.-G. (2017). Predicting customer churn in Mobile industry Using Data Mining technology. Emerald .

[11]Filip, A. (2013). Complaint Management : Customer Satisfaction Learning Process. Elsevier, 271-275.

[12] Ghozali, I. (2014). Structural Equation Modeling Metode Alternatif Dengan Partial Least Squares (PLS). Semarang: Badan Penerbit Universitas Diponegoro Semarang. 
[13] Gunnvald B. Svendsen, N. K. (2013). The effect of brand on churn in the Telecomunication Sector. Emerald, European Journal of Marketing.

[14] Gurning, R. A. (2016). Dampak Mobile Service Quality dan Switching CostTerhadap Kepuasan dan Loyalitas Pelanggan Telkomsel-Survey pada Pengguna Kartu Halo di Pekanbaru. Tesis Pasca Sarjana Univeristas Riau, Pekanbaru, 110.

[15] gursory, U. t. (2010). Customer Churn Analysis in Telecomunication Sector. Istambul university Journal of the school of bussines Administration.

[16] Hair et. al., J. F. (2010). Multivariate Data Analysis. Prentice-Hall.

[17] HarsanDaldeep Kaur, H. s. (2005). Satisfaction,trust,and loyalty: investigating the mediating effct of commitment,switching cost and corporate image. Emerald Journal .

[18] Hsin Hsin Chang, S. W. (2008). The impact of customer interface quality, satisfaction, and Switching Cost on e-loyalty: Internet Experiance as moderator. Elsevier, 10.

[19] Ilias Santouridis, P. T. (2012). Investigating the impact of service quality and customer satisfaction on customer loyalty in mobile telephony in Greece. Emerald Group Publishing.

[20] Indrawati, P. (2015). Metode Penelitian Manajemen dan Bisnis, Konvergensi Teknologi Komunikasi dan Informasi. Bandung: PT Refika Aditama.

[21] Izogo, E. E. (2017). Customer loyalty in telecom service sector: the role of service quality and. The TQM Journal, 17.

[22] Jae-Hyeon Ahn, S.-P. H.-S. (2006). Customer churn analysis: Churn determinants and mediation effect of Partial defection in the korean mobile telecomunication industri. elsevier.

[23] Jatmiko, L. D. (2019, maret ). Bisnis. Retrieved from Telkomsel: https:/teknologi.bisnis.com/read/20190311/84/898453/telkomsel-rajin-uji-coba-5g

[24]Kotler, G. A. (2015). Marketing An Introduction 12th Edition (12 ed.). England: Pearson Education Limited.

[25] Kotler, P., \& Armstrong, G. (2012). Principles of Marketing (14th Ed). New Jersey: Prentice Hall.

[26] Kotler, P., \& Keller, K. L. (2016). Marketing Management. New Jersey: Pearson Education.

[27] Kurt Matzler, A. S. (2015). Switching experience, customer satisfaction, and switching costs in the ICT industry. Emerald- Journal of Service Management, 15.

[28] Malcolm Mc Donald, I. D. (2004). Market Segmentation. Oxford: Elsevier.

[29] Neeru Sharma, P. G. (2000). Switching costs, alternative attractiveness and experience as moderators of relationship commitment in professional,consumer services. Emerald Journal .

[30] Sekaran, U. (2006). In Research Methods For Business : Buku 2 (4th Ed). Jakarta: Salemba Empat.

[31] Sitinjak, S. d. (2006). Strategi Menaklukkan Pasar Melalui Riset Ekuitas dan Perilaku Merek. indonesia.

[32] Solomon, M. R. (2013). Consumer Behaviour: Buying, Having, and Being (10th). New Jersey: Prentice Hall.

[33] The Mobile Economic Report 2018,

[34] Churn Report during 2018 on telco Company 